\title{
Література:
}

1. Треушников М. К. Судебные доказательства. М.: ОАО «Издательский дом «Городец», 2004. 272 с.

2. Гражданский процесс: Учебник / Под ред. В. А. Мусина, Н. А. Чечиной, Д. М. Чечота. М. : «Проспект», 1997. 480 с.

3. Васьковский Е. В. Учебник гражданского процесса. Под редакцией и с предисловием В. А. Томсинова. М. : Издательство «Зерцало», 2003. 464 с.

4. Проблемы науки гражданского процессуального права / В. В. Комаров, $\quad$ В. А. Бигун, В. В. Баранкова; Под ред. проф. В. В. Комарова. Харьков : Право, 2002. 440 с.

DOI https://doi.org/10.30525/978-9934-588-92-1-36

\section{ДО ПИТАННЯ ЩОДО ПРОБЛЕМ УДОСКОНАЛЕННЯ ЦИВІЛЬНОГО ЗАКОНОДАВСТВА НА СУЧАСНОМУ ЕТАПІ}

\author{
Куриліна В. В. \\ студентка магістратури другого року навчання \\ Інституту права
}

Київського національного університету імені Тараса Шевченка

м. Київ, Украӥна

Важко заперечувати, що постійне вдосконалення законодавства $€$ одним із найвагоміших засобів забезпечення ефективності функціонування правової системи держави. Зважаючи на це, цивілістична наука України має своїм основним завданням проведення досліджень, спрямованих на вдосконалення чинного цивільного законодавства [1, с. 53].

На сьогодні можна констатувати наявність низки проблем цивільного законодавства, серед яких:

- неузгодженість понятійного апарату, термінологічні неточності, відсутність нормативно закріплених визначень понять чи різне їх трактування у різних актах цивільного законодавства;

- недостатність чи відсутність законодавчої регламентації окремих видів суспільних відносин;

- відсутність легальної чіткої ієрархії законів, концептуальна неузгодженість нових юридичних норм із прийнятими раніше, колізії між актами цивільного законодавства та ін. [2, с. 61]. 
Аналізуючи сучасний стан цивільного законодавства України та тенденції його розвитку, не можна не зазначити про ідею рекодифікації Цивільного кодексу України.

Ідея рекодифікації Цивільного кодексу України була висунута на початку 2019 року [3]. Так, у статті А. Довгерта, присвяченій даній темі, термін «рекодифікація» був вжитий автором у значенні системних суттєвих змістовних і структурних новацій чинного кодексу (або групи кодексів та законів), без створення нового. Науковець обгрунтовував, що проведення рекодифікації ЦК України потребує логіка подальшої трансформації суспільства, а саме формування правдивої й ефективної ринкової економіки як невід'ємної складової громадянського суспільства, а також те, що основним напрямом рекодифікації ЦК України є подальша «європеїзація» кодексу [4].

17 липня 2019 р. Кабінет Міністрів України прийняв постанову за № 650 «Про утворення робочої групи щодо рекодифікації (оновлення) цивільного законодавства України», якою було утворено робочу групу щодо рекодифікації цивільного законодавства та затверджено Положення про неї. Під час здійснення рекодифікації особлива увага, на мою думку, має бути присвячена таким проблемним аспектам, як:

- Конкуретність та неузгодженість положень Цивільного кодексу України та Господарського кодексу України. На сьогодні фактично не вирішена проблема подвійного правового регулювання значного кола відносин (договірних, корпоративних тощо) двома різними кодифікованими законами та відсутності правових механізмів (способів) усунення суперечностей між нормами цих двох кодексів [5].

- Актуальною залишається проблема більш детального регулювання особистих немайнових прав, які $\epsilon$ предметом цивільноправової охорони. Зокрема, це стосується права на життя (в т.ч. проблема евтаназії), права на здоров'я тощо [6, с. 3-5]. Слід визнати, що значна кількість норм книги другої ЦК України у зв'язку з високим рівнем їх декларативності до цього часу не отримала широкого практичного застосування. Ще одна частина норм книги другої ЦК України фактично не отримала цивільно-правового змісту, що, незважаючи на їх практичну значущість, перешкоджає застосуванню цих норм для правового регулювання цивільно-правових відносин. Наочним прикладом щодо останнього твердження $\epsilon$ норми, які містяться в ст. 315 ЦК України «Право на мирні зібрання». Зазначені норми в частині першій та другій цієї статті не лише не містять самостійного змістовного навантаження, а й, що більш важливо, 
сформульовані радше як конституційно-правові норми, що регулюють конституційно-правові, а не цивільно-правові відносини [5].

- У сфері права інтелектуальної власності активному науковому дослідженню підлягають наступні аспекти: проблеми законодавчого встановлення правового режиму комерційних таємниць та «ноу-хау», перспективи законодавчого регулювання та охорони якісно нових результатів творчої діяльності (наприклад, Інтернет (веб) - сторінок); розв'язання термінологічних суперечностей між Цивільним кодексом України та спеціальними законами [6, с. 3-5].

- Із тексту загальних положень ЦК України не випливає те, що в регулюванні цивільних відносин враховується загальновідомий принцип верховенства права (натомість закріплені такі засади цивільного законодавства, як справедливість, добросовісність та розумність). Підтвердженням потреби легалізації принципу верховенства права безпосередньо в тексті ЦК $є$ те, що в результаті прийняття нової редакції процесуальних кодексів, зокрема, ЦПК України, поняття верховенства права неодноразово згадується в тексті цього кодифікованого закону [5].

Безперечно, вищеназвані проблемні питання $є$ лише частиною тих аспектів, на які має бути звернута увага під час ре кодифікації. Більше того, цивільне законодавство регулює відносини, які постійно розвиваються та ускладнюються, що, у свою чергу, призводить до необхідності його вдосконалення та впровадження нових правових моделей та інститутів - при цьому таке впровадження, безумовно, має відбуватись поступово та обдумано, 3 детальним науковим осмисленням та обгрунтуванням [7, с. 67].

Потрібно зазначити: важливий напрямок розвитку і вдосконалення цивільного законодавства - це його адаптація до стандартів Європейського Союзу. На цьому шляху має бути проведена велика робота по усуненню дублювання та розбіжностей у сфері договірного права, по оновленню масиву підзаконних нормативно-правових актів, а також договірної та судової практики щодо застосування цивільного i господарського законодавства [8, с. 55]. Так, економічні інтеграційні процеси потребують відповідної правової інтеграції, зокрема, поступового наближення правового забезпечення майнових відносин товарного характеру в Україні до умов внутрішнього ринку СС, до правових засад і принципів, що діють на цьому ринку, 3 метою досягнення сполучності з нормами права $С$ та країн-членів, а згодом гармонізації, а також уніфікації в деяких галузях [9, с. 5]. Уніфікація йде шляхом зближення та гармонізації цивільно-правових систем 
різних держав внаслідок запозичення відповідних правових конструкцій та згладжування принципових відмінностей між закономірностями правового регулювання та охорони суспільних відносин [10].

Отже, вдосконалення цивільного законодавства передбачає усунення наявних у ньому на сьогодні неузгодженостей, суперечностей і прогалин, скасування неефективних і застарілих норм та впровадження нових, узгоджених із європейськими стандартами, підходів до регулювання суспільних відносин. Анонсований процес рекодифікації має сприяти досягненню перерахованих завдань та в цілому забезпечити модернізацію змісту законодавчого регулювання існуючих відносин.

\section{Література:}

1. Кузнєцова Н. С., Кохановська О. В. Сучасне приватне право України: вектори європейського розвитку. Вісник Національної академії правових наук України № 3 (86) 2016. Ст. 49-54. [Електронний pecypc]. - Режим доступу: http://visnyk.kh.ua/web/uploads/pdf/ JNALSV_49-55.pdf

2. Біленська Д. О. Шляхи вдосконалення правового регулювання інформаційних правовідносин в Україні. Форум права. - 2013. - № 1. C. 60-64. [Електронний ресурс]. - Режим доступу: http://nbuv.gov.ua/ UJRN/FP_index.htm_2013_1_12

3. Щербина В. С. До питання щодо рекодифікації цивільного законодавства / Ресурс: веб-сайт «Голос України». [Електронний peсурс]. - Режим доступу: http://www.golos.com.ua/article/325640

4. Довгерт, А. Рекодифікація Цивільного кодексу України: основні чинники і передумови для старту // Право України. - Київ, 2019. № 1. - С. 27-41. [Електронний ресурс]. - Режим доступу: https://www.researchgate.net/publication/331266621_Rekodifikacia_Civilno go_kodeksu_Ukraini_osnovni_cinniki_i_peredumovi_dla_startu

5. Первомайський О. О. Кодифікація цивільного законодавства: проміжні результати та подальші перспективи. // Приватне право i підприємництво. - 2018. [Електронний ресурс]. - Режим доступу: http://nbuv.gov.ua/j-pdf/Ppip_2018_18_7.pdf

6. Кучер В. О. Перспективи розвитку цивільного права в Україні. Актуальні проблеми розвитку приватного права в Україні: тези доповідей учасників курсантсько-студентської конференції (15 квітня 2016 р.) / За ред. В.О. Кучера, Г.Б. Яновицької. - Львів:2016. - 525 с. [Електронний ресурс]. - Режим доступу: http://www.lvduvs.edu.ua/ documents_pdf/biblioteka/nauk_konf/konf_15_04_2016.pdf 
7. Костова Н. І. Прогалини вдосконалення цивільного законодавства. Наукові записки міжнародного гуманітарного університету. № 18. - 2013 p. - С. 66-69. [Електронний ресурс]. - Режим доступу: http://www.sci-notes.mgu.od.ua/archive/v18/26.pdf

8. Луць В. В. Договірне право України: сучасний стан і тенденції розвитку. Юридичний вісник. Повітряне і космічне право. - 2009. № 2. - С. 52-55. [Електронний ресурс]. - Режим доступу: http://nbuv.gov.ua/UJRN/Npnau_2009_2_12

9. Вишняков О. К. Апроксимація правового забезпечення цивільних майнових відносин в Україні до умов внутрішнього ринку Європейського Союзу: дис. д-ра юрид. наук / О. К. Вишняков. - Одеса, 2008. [Електронний ресурс]. - Режим доступу: http://dspace.onua.edu.ua/ handle/11300/8569

10. Стефанчук Р. О. Цивільне право України: навчальний посібник. К.: Прецедент, 2005. [Електронний ресурс]. - Режим доступу: http://www.ebk.net.ua/Book/law/stefanchuk_tsivpu/zmist.htm

DOI https://doi.org/10.30525/978-9934-588-92-1-37

\title{
КАМКОРДИНГ ЯК ПОРУШЕННЯ АВТОРСЬКИХ ПРАВ НА КІНЕМАТОГРАФІЧНИЙ ТВІР
}

\author{
Лубчук О. Д. \\ аспірантка кафедри інтелектуальної власності, \\ інформаційного та корпоративного права \\ Львівського національного університету імені Івана Франка \\ м. Львів, Україна
}

Камкординг - один 3 найбільш поширених видів піратства у кінематографічній сфері. В Україні на законодавчому рівні поняття камкордингу було закріплено після прийняття 23 березня 2017 року Закону України «Про державну підтримку кінематографії в Україні» [1]. Внаслідок прийняття наведеного Закону були внесені відповідні доповнення у Закон України «Про авторське право і суміжні права» [2]. Одним із таких доповнень стало визначення поняття камкордингу як відеозапису аудіовізуального твору під час його публічної демонстрації в кінотеатрах, інших кіновидовищних закладах особами, які перебувають у тому самому приміщенні, де відбувається така публічна 